\title{
PENGARUH MODEL REALISTIC MATHEMATICS EDUCATION TERHADAP KEMAMPUAN LITERASI MATEMATIKA SISWA KELAS V SEKOLAH DASAR GUGUS XIV KOTA BENGKULU
}

\author{
Fasadena Saraseila ${ }^{1}$, V. Karjiyati ${ }^{2}$, Neza Agusdianita $^{3}$ \\ ${ }^{1,2,3}$ Program Studi PGSD, FKIP Universitas Bengkulu \\ Fasadenasaraseila@gmail.com ${ }^{1}$, Vkajiyati@gmail.com², Neza.agusdianita@gmail.com³
}

\begin{abstract}
This study aims to determine the effect of Realistic Mathematics Education models on the ability of mathematics literacy of fifth grade students of the XIV Cluster Elementary School in Bengkulu City. This research is a quantitative research. The method used is quasy experimental with desigen type is the matching only pretest-posttest control group design. The population in this study was the elementary school cluster XIV Bengkulu City. The sampling technique used cluster random sampling. The sample in this study was class V at SDN 42 Bengkulu City as an experimental class and class $V$ at SDN 24 Bengkulu City as a control class. The research instrument used in the form of a test sheet in the form of a description of 4 squestions. Taking the test twice, namely before and after learning takes place in the experimental and control classes. Based on the $t$-test calculation of the students' posttest results, where $t_{\text {count }}=4.09$ and $t_{\text {table }}=2.07$. Because $t_{\text {count }}>t_{\text {table }}$, it can be concluded that there is a significant difference on the use of realistic mathematics education models on the ability of mathematics literacy of fifth grade students in the XIV group of Bengkulu city.
\end{abstract}

Keywords: Realistic Mathematics Education, Mathematical Literacy Ability

\section{PENDAHULUAN}

Matematika merupakan salah satu bidang studi yang memiliki sifat khas dan selalu digunakan dalam memecahkan masalah di kehidupan sehari-hari. Matematika dikenal sebagai ilmu pengetahuan yang bersifat abstrak, artinya hanya ada di dalam pemikiran. Menurut Abidin, dkk (2018) proses pengabstrakan itu dilakukan dengan mempresentasikan permasalahan yang ada ke dalam bentuk model matematika dengan demikian dibutuhkan pemahaman yang baik untuk memaknai konsep- konsep matematika. Karakteristik matematika yang bersifat abstrak ini yang menyebabkan anak merasa kesulitan dalam memahami pembelajaran matematika, sehingga matematika masih menjadi matapelajaran yang kurang disenangi siswa dan dianggap sebagai mata pelajaran yang sulit.

Dalam Programme for International Student Assessment (PISA) rendahnya kemampuan literasi matematika anak Sekolah Dasar Indonesia terlihat dari hasil tahun 2000 hingga 2018. PISA menempatkan siswa Indonesia pada peringkat bawah dibandingkan negaranegara Organisation for Economic Cooperation and Development (OECD) lainnya. Pada PISA tahun 2018 Indonesia menduduki peringkat 72 dari 78 negara dengan perolehan skor 379 dari 591 yang didapat dari China sebagai peringkat tertinggi dan skor 569 yang didapat dari negara tetangga yaitu Singapura. Sementara itu, dari hasil Trends in International Mathematics and Science Study (TIMMS) tahun 2016, Indonesia memperoleh skor 395 dari skor rata-rata 500. Skor tertinggi didapatkan Singapura dengan skor 618 yaitu 50\% lebih tinggi daripada Indonesia (Han, dkk. 2017:1). Hal ini menunjukkan bahwa kemampuan literasi matematika siswa Indonesia masih rendah dan tertinggal.

Banyak faktor yang menyebabkan rendahnya kemampuan literasi matematika siswa salah satunya adalah kurangnya pembiasaan dari guru dalam menyelesaikan masalah yang berkaitan dengan soal literasi matematika. Kenyataan ini banyak dijumpai 
dalam pembelajaran matematika di kelas, pembelajaran yang berlangsung hanya berpusat pada guru yang hanya menjelaskan sehingga siswa menjadi pasif. Sejalan dengan pendapat Diyarko dan Waluyo (2016: 71) yang mengatakan bahwa faktor yang menyebabkan rendahnya skor kemampuan literasi siswa yaitu kesulitan siswa dalam menyelesaikan soal literasi matematika, tidak adanya pembiasaan dari guru dengan soal-soal literasi matematika, factor metode dan media yang digunakan kurang mendukung pembelajaran.

Literasi matematika merupakan kemampuan seseorang untuk merumuskan, mengunakan dan menafsirkan matematika dalam berbagai konteks. Sejalan dengan pendapat Astuti (2018) dalam artikelnya "Kemampuan Literasi Matematika dan Kemampuan Berpikir Tingkat Tinggi““ Literasi matematika diartikan sebagai kemampuan seseorang untuk merumuskan, menerapkan dan menafsirkan matematika dalam berbagai konteks, termasuk kemampuan melakukan penalaran secara matematis dan menggunakan konsep, prosedur, dan fakta. Literasi berkaitan erat dengan kemampuan memecahkan masalah yang berkaitan dengan menulis, membaca, sains dan matematis. Literasi matematika sangat penting pada kehidupan individu karena berkaitan dengan pekerjaan seharihari yang menggunakan penalaran yang menggunakan logika dalam setiap pengambilan keputusan. Oleh karena itu, proses penyelesaian masalah nyata menjadi komponen penting dalam literasi matematika.

Literasi matematika menuntut siswa memiliki kemampuan penalaran dan pemecahan masalah yang menekankan pada berbagai masalah dan situasi dalam kehidupan sehari-hari. Hal ini sejalan dengan pendapat Fathani (2016) dalam artikelnya "Pengembangan Literasi Matematika Sekolah dalam Perspektif Multiple Intelligences" Literasi matematika merupakan kemampuan seseorang untuk merumuskan, menggunakan dan menafsirkan matematika dalam berbagai konteks masalah kehidupan sehari-hari secara efisien. Tujuan pembelajaran matematika di sekolah dasar adalah agar siswa mampu dan terampil menggunakan matematika dalam kehidupan sehari-hari. Untuk mencapai tujuan tersebut, maka pembelajaran diarahkan kepada konsepkonsep dalam kompetensi dasar yang diajarkan. Depdiknas dalam Wijaya (2012:16) menjelaskan bahwa pembelajaran matematika bertujuan supaya siswa memiliki kemampuan memahami konsep matematika, menggunakan penalaran pada pola dan sifat, memecahkan masalah, mengkomunikasikan gagasan dengan media serta memiliki sikap menghargai matematika dalam kehidupan. Dengan pembelajaran yang menggunakan situasi nyata untuk menemukan konsep, maka dapat mengembangkan kemampuan literasi matematika siswa.

Kemampuan literasi dalam pembelajaran matematika dapat dikatakan sebagai standar yang harus dikuasai oleh siswa untuk menumbuhkembangkan keterampilan matematika. Oleh karenaitu guru harus memahami tentang karakteristik matematika agar dalam menyampaikan materi dapat mudah dipahami oleh siswa dengan menggunakan situasi nyata sesuai dengan karakteristik anak SD yang lebih menyukai benda-benda nyata. Model yang mengangkat pada konteks kehidupan nyata sebagai sumber belajar yaitu model Realistic Mathematics Education(RME). Sejalan dengan pendapat Hadi (2017) di dalam model RME pembelajaran dilakukan dimulai dari sesuatu yang nyata sehingga siswa dapat terlibat dalam proses pembelajaran yang bermakna.

Model RME merupakan suatu pendekatan dalam pembelajaran matematika yang menggunakan konteks atau permasalahan realistik. Model RME mengacu pada pernyataan Freudenthal dalam Shoimin (2014) yang mengatakan bahwa matematika harus dikaitkan dengan realitas dan matematika merupakan aktivitas manusia. Menurut Susanto (2013) RME merupakan suatu pendekatan yang berorientasi pada siswa dengan prinsip utama siswa harus aktif berpartisipasi dalam proses pembelajaran. Pendapat di atas menunjukan bahwa model RME memberikan kesempatan kepada siswa untuk bernalar dengan menemukan sendiri 
secara aktif konsep matematika dan pemecahan masalah yang ada pada situasi nyata.

Pada dasarnya prinsip atau ide yang mendasari RME adalah situasi ketika siswa diberi kesempatan untuk menemukan kembali ide-ide matematika menggunakan lingkungan sekitar dan dunia nyata. Dalam penelitian yang dilaksanakan oleh Karjiyati, dkk (2014) dalam jurnal ilmiah PGSD UNIB Pembelajaran matematika dengan model Quantum Teaching dengan RME berdasarkan hasil uji coba terbatas menunjukkan bahwa dapat meningkatkan pemahaman konsep, kreativitas dan pengembangan karakter siswa SD. Model RME memiliki keunggulan yaitu memberikan permasalahan kepadasiswa yang erat kaitanya dengan kehidupan sehari-hari siswa sehingga siswa dapat dengan mudah memahami konsep yang disampaikan (Wahyu, 2016:7). Dalam pembelajaran RME guru juga dapat menggunakan media yang berupa benda konkret yang ada di lingkungan sekitar siswa atau berkaitan dengan kehidupan sehari-hari siswa.

Bedasarkan analisis kurikulum 2013, pada mata pelajaran matematika di kelas V semester II terdapat Kompetensi Dasar (KD) 3.5 Menjelaskan, dan menentukan volume bangun ruang dengan menggunakan satuan volume (seperti kubus satuan) serta hubungan pangkat tiga dengan akar pangkat tiga. Penguasaan materi dan konsep volume bangun ruang kubus dan balok sangat penting karena banyak digunakan untuk memecahkan masalah dalam kehidupan sehari-hari. Materi ini dalam aplikasiya diajarakan dengan menggunakan model RME dengan belajar menggunakan konteks masalah dalam kehidupan sehari-hari siswa dapat bernalar, menemukan konsep dan berpikir kreatif maka dari itu siswa dapat mengembangkan kemampuan literasi matematikanya. Literasi matematika memiliki 3 komponen yaitu komponen proses, konten dan konteks. Komponen literasi matematika yang diteliti oleh peneliti yaitu komponen konteks.

Berdasarkan uraian di atas, maka tujuan penelitian ini yaitu untuk menganalisis pengaruh model Realistic
Mathematics Education terhadap kemampuan literasi matematika komponen konteks siswa kelas V SD Gugus XIV Kota Bengkulu.

\section{METODE}

Penelitian ini merupakan penelitian kuantitatif dengan metode eksperimen. Metode penelitian eksperimen yang digunakan adalah quasi eksperiment (eksperimen semu). Desain pada penelitian ini adalah the matching only pretest-posttest group design. Desain ini membutuhkan dua kelompok subyek yang dipilih secara acak di dalam kelompok tersebut. Masingmasing kelompok diberikan tes sebanyak dua kali, yakni pretest dan posttest.

Populasi adalah keseluruhan subyek atau obyek penelitian. Menurut Sudaryono (2016) yang mengatakan bahwa populasi adalah wilayah generalisasi yang terdiri dari objek atau subjek yang mempunyai kualitas dan karakteristik yang telah tentukan oleh peneliti. Populasi pada penelitian ini adalah seluruh kelas IV SD pada gugus XIV kota Bengkulu yang terdiri dari SDN 42 Kota Bengkulu, SDN 45 Kota Bengkulu, SDN 52 Kota Bengkulu dan SDN 24 Kota Bengkulu.

Sampel merupakan bagian kecil dari populasi. Menurut Sudaryono (2016: 120) sampel adalah bagian dari jumlah dan karakteristik yang dimiliki oleh populasi tersebut. Teknik pengambilan sampel dengan cara cluster random sampling. Menurut Winarni (2018) teknik ini digunakan jika dijumpai populasi yang heterogen karena sub populasi suatu kelompok (cluster) yang mempunyai sifat heterogen. Selain itu, teknik ini digunakan apabila daftar dari seluruh unit populasi tidak diperoleh sehingga cukup dengan daftar cluster.

Sampel diambil secara acak dan dilakukan dengan mengundi seluruh kelas $\mathrm{V}$ di SD Negeri dari seluruh populasi. Empat SD Negeri gugus XIV yang terakreditasi A di Kota Bengkulu diundi sehingga diperoleh dua kelas yang akan menjadi tempat percobaan yaitu kelas V B SDN 42 Kota Bengkulu sebagai kelas eksperimen dan kelas V A SDN 24kota Bengkulu sebagai kelas kontrol. 


\section{HASIL PENELITIAN DAN PEMBAHASAN}

Sampel dalam penelitian ini yaitu SDN 42sebagai kelas eksperimen dan SDN 24 sebagai kelas kontrol. Tahap awal penelitian, yaitu melaksanakan pretest pada kelas eksperimen dan kelas kontrol. Selanjutnya, kedua kelas diberikan perlakuan yang berbeda yaitu pada kelas eksperimen menggunakan model pembelajaran RME dan pada kelas control menggunakan model pembelajaran eksplorasi, elaborasi dan konfirmasi (EEK). Setelah diberikan perlakuan kelas eksperimen dan kelas kontrol melaksanakan posttest. Dalam penelitian ini, data diperoleh berdasarkan hasil pretest dan posttest kelas eksperimen dan kelas kontrol.

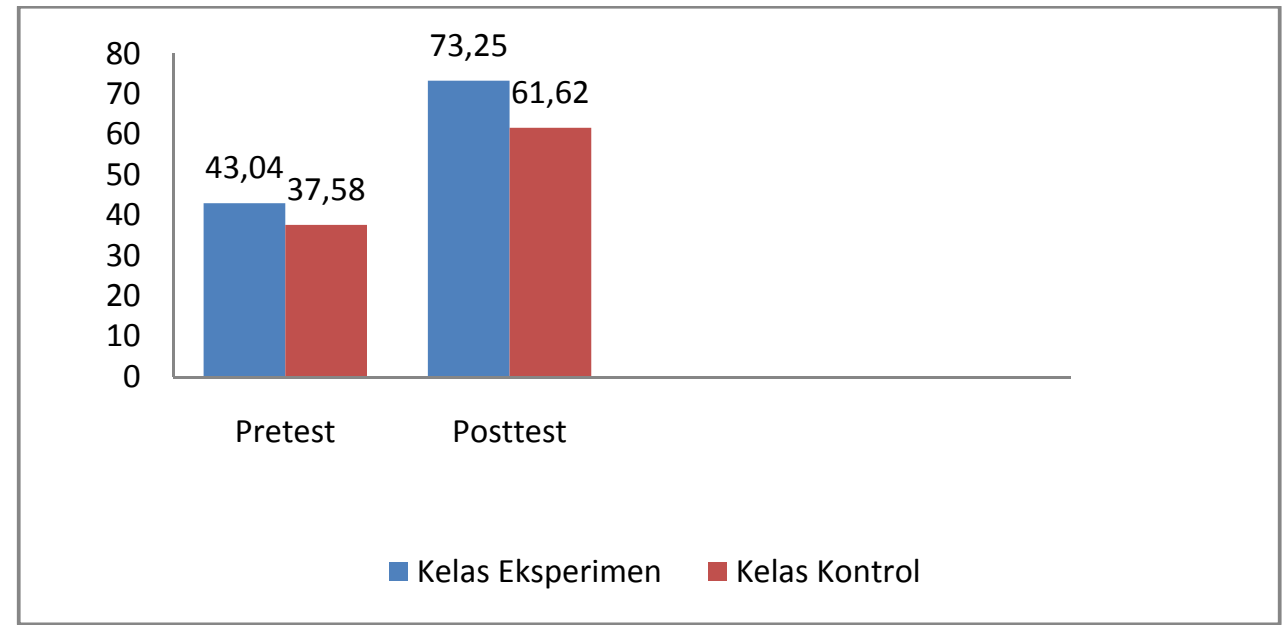

Gambar 1. Diagram rata-rata hasil pretest dan posttest

Adapun skor rata-rata pretest dari kedua kelas yaitu pada kelas eksperimen 43,04, sedangkan kelas kontrol sebesar 37,58. Skor rata-rata posttest kelas eksperimen sebesar 73,25 dan kelas control sebesar 61,62. Hasil perhitungan pada kelas eksperimen menunjukkan bahwa $\chi^{2}$ hitung $<\chi^{2}$ rabel pada taraf signifikan $5 \%$ sebesar 11,07 nilai $\chi^{2}{ }_{\text {hitung }}$ untuk pretest sebesar 10,75 dan posttest sebesar 1,52. Untuk kelas kontrol, hasil perhitungan juga menunjukkan bahwa $\chi^{2}{ }_{\text {hitung }}<\chi_{\text {rabel }}$ pada taraf signifikan $5 \%$ sebesar 11,07 dengan nilai $\chi^{2}$ hitung untuk pretest sebesar $-14,27$ dan posttest sebesar 7,45. Hasil ini memberikan indikasi bahwa kelas eksperimen dan kelas kontrol berdistribusi normal.

Setelah melakukan uji normalitas kedua sampel. Selanjutnya dilakukan uji homogenitas. Berdasarkan data hasil perhitungan yang diperoleh menunjukkan bahwa nilai $\mathrm{f}_{\text {hitung }}<\mathrm{f}_{\text {tabel }}$ yaitu pada pretest kelas eksperimen dan kelas control $\mathrm{f}_{\text {hitung }}$ sebesar 1,26 $<\mathrm{f}_{\text {tabel }}$ sebesar 1,98. Sedangkan pada posttest kelas eksperimen dan kelas kontrol $\mathrm{f}_{\text {hitung }}$ sebesar $1,73<\mathrm{f}_{\text {tabel }}$ sebesar 1,98. Artinya status varian kelas eksperimen dan kelas kontrol berasal dari varian yang homogen.

Langkah terakhir dilakukan pengujian hipotesis penelitian yang dilakukan menggunakan uji-t. apabila $t_{\text {hitung }}<t_{\text {tabel }}$ berarti tidak terdapat pengaruh penggunaan model Realistic Mathematics Education Terhadap Kemampuan Literasi pada Pembelajaran Matematika Siswa Kelas V SDN Gugus XIV Kota Bengkulu dan sebaliknya, jika $t_{\text {hitung }}>t_{\text {tabel }}$ berarti terdapat pengaruh penggunaan model Realistic terhadap Kemampuan Literasi pada Pembelajaran Matematika Siswa Kelas V SDN Gugus XIV Kota Bengkulu. Hasil pengujian hipotesis untuk data pretest menunjukkan bahwa nilai $t_{\text {hitung }}$ sebesar 1,48 lebih kecil daripada $t_{\text {tabel }}$ sebesar 2,07. Untuk $\mathrm{t}_{\text {hitung }}$ berada di daerah penerimaan $\mathrm{H}_{0}$ dan penolakan $\mathrm{H}_{\mathrm{a}}$. Artinya sebelum dilakukan perlakuan pada kelas eksperimen tidak terdapat pengaruh penggunaan model pembelajaran Realistic Mathematics Education terhadap Kemampuan Literasi 
Matematika Komponen Konteks Siswa. Adapun skor rata-rata posttest menunjukkan bahwa nilai $t_{\text {hitung }}$ sebesar 4,09 lebih besar daripada $t_{\text {tabel }}$ sebesar 2,07. Untuk $t_{\text {hitung }}$ berada di daerah penerimaan hipotesis $\left(\mathrm{H}_{\mathrm{a}}\right)$ dan penolakan hipotesis $\left(\mathrm{H}_{0}\right)$

Berdasarkan pengujian data di atas dapat diketahui bahwa kedua sampel berdistribusi normal dan homogen, maka pengujian ini dilanjutkan dengan menggunakan uji-t. Dalam perhitungan Uji-t, apabila $t_{\text {hitung }}<t_{\text {tabel }}$ berarti tidak terdapat perbedaan signifikan antara kelas eksperimen dan kelas kontrol dan sebaliknya jika $t_{\text {hitung }}>t_{\text {tabel }}$ berarti terdapat perbedaan signifikan antara kelas eksperimen dan kelas kontrol. Berdasarkan hasil uji-t menunjukkan bahwa nilai $t_{\text {hitung }}$ untuk data posttest menunjukkan bahwa nilai $t_{\text {hitung }}$ sebesar 4,09 lebih besar daripada nilai $t_{\text {tabel }}$ sebesar 2,07. Terdapat pengaruh signifikan kemampuan literasi komponen konteks antara kelas eksperimen dan kelas kontrol, hal ini disebabkan adanya perbedaan perlakuan antara kelas eksperimen dan kelas kontrol yaitu penggunaan model pembelajaran. Pada kelas eksperimen model pembelajaran digunakan yaitu model pembelajaran Realistic Mathematics Education, sedangkan pada kelas control tidak menggunakan model EEK. Sehingga dapat disimpulkan bahwa model pembelajaran Realistic Mathematics Education berpengaruh terhadap kemampuan literasi matematika komponen konteks siswa.

Perbedaan nilai rata-rata pada kelas eksperimen dan control dikarenakan kelas eksperimen yang menggunakan model pembelajaran RME dengan media bendabenda yang ada disekitar siswa dan model bangun ruang dalam proses pembelajaran lebih tinggi dibandingkan kelas kontrol yang menggunakan model pembelajaran EEK. Hal ini dikarenakan pada kelas eksperimen siswa sendirilah yang menemukan konsep volume bangun ruang sehingga hal itu akan mudah diingat oleh siswa. Sedangkan pada kelas kontrol siswa hanya mengamati setiap konsep volume bangun ruang yang menggunakan media gambar sehingga kemampuan siswa untuk mengingat konsep tersebut lebih rendah jika dibandingkan dengan pengalaman langsung menggunakan model RME. Sejalan dengan pendapat Ajun (2013:74) pembelajaran RME dilakukan melalui permalasahan berbagai situasi dan persoalan-persoalan "realistik" yakni yang berkaitan dengan situasi yang dapat dibayangkan siswa. Dalam pembelajaran $R M E$ guru juga menggunakan media yang berupa benda konkret yang ada di lingkungan sekitar siswa atau berkaitan dengan kehidupan sehari-hari siswa.

Pada kelas eksperimen, proses pembelajaran menggunakan model RME. Langkah-langkah model RME berpengaruh terhadap kemampuan literasi matematika komponen konteks siswa yaitu siswa lebih memahami konsep dan mengaplikasikannya dalam menyelesaikan suatu permasalahan. Langkah-langkah model RME yaitu langkah memahami masalah kontekstual, langkah menyelesaikan masalah kontekstual, langkah membandingkan dan mendiskusikan jawaban, serta langkah terakhir yaitu menarik kesimpulan berpengaruh terhadap indicator komponen konteks memodelkan, memecahkan masalah dan menerapkan.

Langkah pertama dalam model RME yaitu memahami masalah kontekstual. Pada langkah ini siswa diarahkan kepada masalah berkaitan dengan bangun ruang menggunakan kotak teh dan tisu serta model bangun ruang kubus dan balok dengan mengingat pengalamannya sendiri. Ketika siswa mampu menyebutkan unsurunsur bangun ruang dan bertanya jawab mengenai cara menemukan volume bangun ruang mereka mengingat dan mengaitkan pengalamannya dengan topik pembelajaran. Siswa menjadi lebih antusias dengan pemanfaatan benda konkrit yang ada di sekitar siswa dan model bangun ruang meningkatkan minat belajar siswa, sehingga siswa termotivasi dan bertanya mengenai materi pembelajaran. Sejalan dengan pendapat Tampubolon (2016) yang mengatakan model Realistic Mathematics Education dengan memanfaatkan situasi nyata dapat meningkatkan aktivitas siswa sehingga dalam proses pembelajaran siswa lebih aktif bertanya jawab. 


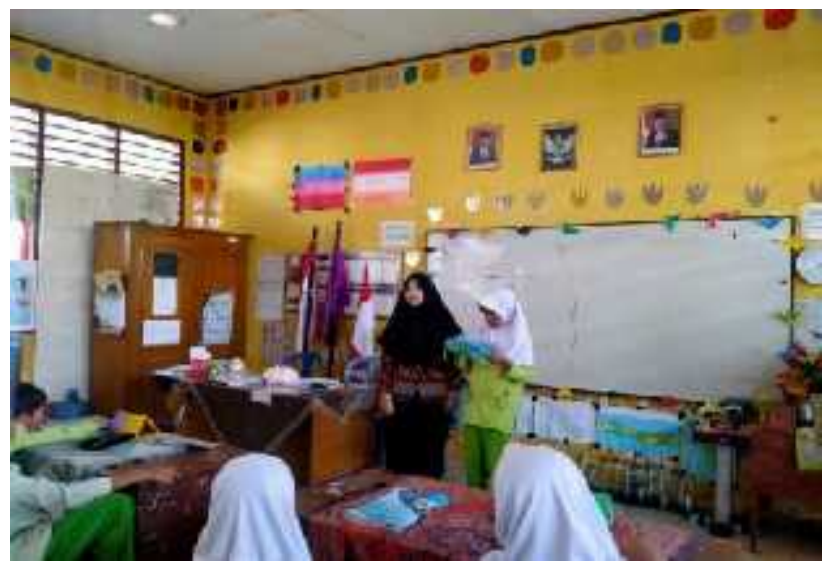

Gambar 2. Siswa diarahkan kepada beberapa masalah kontekstual

Langkah kedua yaitu menyelesaikan masalah kontekstual yang berkaitan tentang volume bangun ruang kubus dan balok. Siswa dibentuk menjadi4 kelompok yang heterogen dan setiap kelompok diberi nama unsur-unsur bangun ruang. Siswa secara berkelompok berdiskusi untuk menyelesaikan masalah. Guru memberikan petunjuk penyelesaian LKPD untuk memudahkan siswa. Siswa diberikan model bangun ruang. Selanjutnya, siswa menemukan volume menggunakan model bangun ruang dan menuliskan jawaban pada lembar LKPD. Setelah mengerjakan
LKPD, siswa dapat mengembangkan komponen konteks kemampuan literasi yaitu memodelkan, memecahkan masalah dan menerapkan. Hal ini sejalan dengan pendapat Wahyuni, dkk (2017) titik awal pembelajaran pada model RME yaitu pada situasi nyata dengan menggunakan benda konkrit yang sehingga mendorong siswa untuk mudah memahami situasi tersebut. Fathurrohman (2017), model RME menekankan pada keterampilan siswa dalam proses (of doing mathematics), berdiskusi dan berkolaborasi sehingga dapat menemukan sendiri.

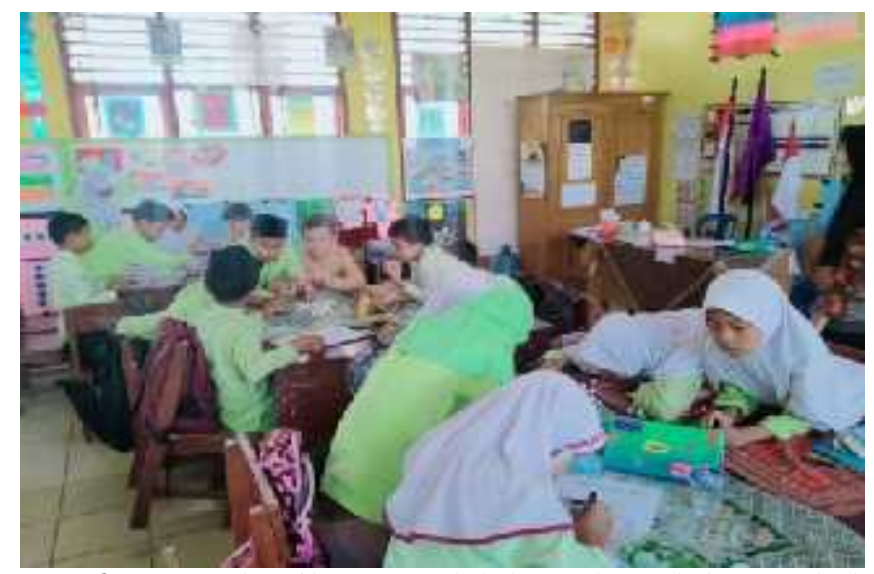

Gambar 3. Menyelesaikan masalah kontekstual dengan kelompok

\begin{abstract}
Langkah selanjutnya yaitu membandingkan dan mendiskusikan jawaban. Siswa diberikan kesempatan untuk membandingkan dan mendiskusikan jawaban masing-masing kelompok serta melaporkan hasil diskusi kelompok ke
\end{abstract}

depan kelas. Pada tahap ini pengetahuan dan pemahaman siswa mengenai penyelesaian masalah berkaitan materi bertambah sehingga komponen konteks kemampuan literasi matematika siswa berkembang. Sejalan dengan Sholahudin 
(2018) yang menjelaskan bahwa, adanya peningkatan pada aspek kemampuan literasi matematika siswa yang memperoleh pembelajaran matematika realistik.

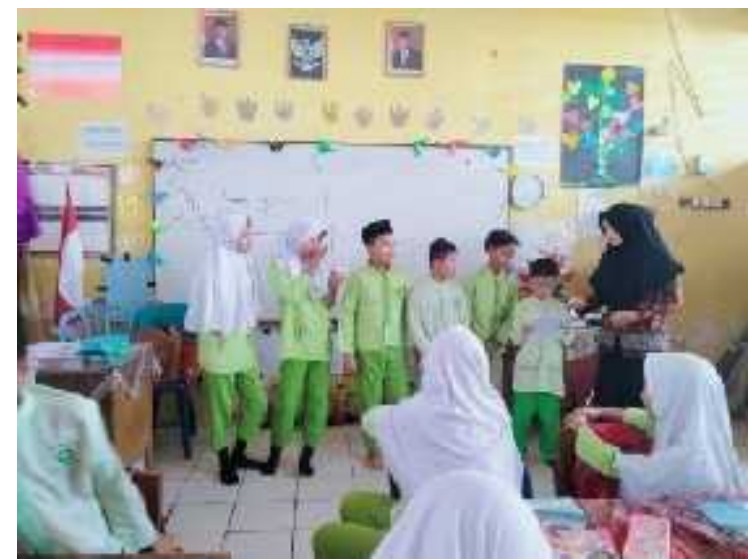

Gambar 4. Membandingkan dan mendiskusikan jawaban antar kelompok

Langkah terakhir yaitu menyimpulkan, pada langkah ini guru memberikan penguatan dan pemantapan materi dan melakukan tanya jawab mengenai pembelajaran yang telah dipelajari. Kemudian, siswa menyimpulkan hasil pembelajaran yang telah dilaksanakan. Hal ini sejalan dengan pendapat Suwarman, dkk (2017) melalui masalah yang bersifat kontekstual pada pembelajaran RME, siswa dilatih untuk dapat memecahkan masalah dengan caranya sendiri serta lebih memahami konsep yang telah dipelajari dan tidak mudah dilupakan oleh siswa.

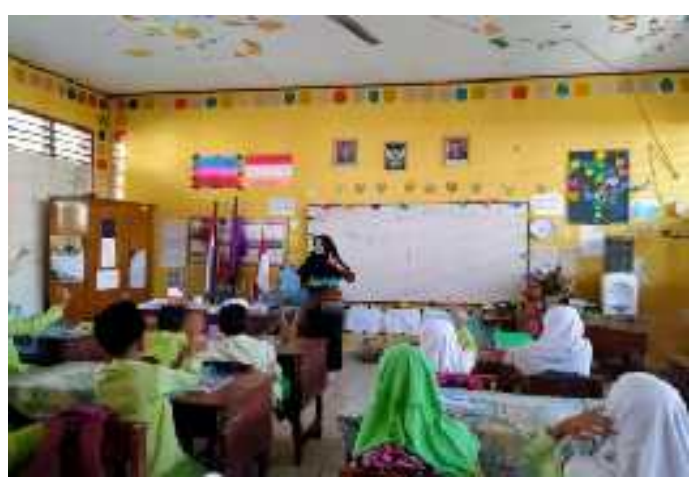

Gambar 5. Siswa bersama guru menarik kesimpulan

Pembelajaran pada kelas kontrol dilakukansebanyakdua kali pertemuan dengan materi yang sama namun dengan model yang berbeda yaitu model EEK. Pelaksanaan pembelajaran dilakukan dengan menyampaikan tujuan pembelajaran terlebih dahulu. Selanjutnya guru menjelaskan konsep volume bangun ruang kubus dan balok. Siswa dan guru melakukan tanya jawab mengenai gambar bangun ruang yang ada di papan tulis, kemudian guru memberikan contoh soal dan soal latihan. Siswa mengerjakan LKPD secara berkelompok. Untuk menemukan konsep volume bangun ruang kubus dan balok siswa menghitung banyak kubus satuan pada gambar. Setelah itu siswa melaporkan hasil diskusi dan memberikan tanggapan mengenai materi.

Terdapatnya pengaruh yang penggunaan model RME terhadap kemampuan literasi matematika siswa dikarenakan dalam pembelajaran matematika menggunakan model RME siswa terlibat secara aktif dan siswa menemukan secara langsung serta mengeksplorasi pengetahuannya, sumber belajar dihadirkan langsung di dalam kelas sehingga siswa mampu membangun kebiasaan berliterasi. 
Setelah pembelajaran di kelas eksperimen dan kelas kontrol selesai, kemudian diberikan posttest pada masingmasing kelas. Hasil posttest menunjukkan bahwa data berdistribusi normal dan homogen dengan rata-rata yaitu kelas eksperimen 73,25 dan kelas kontrol 61,62. Terdapat peningkatan nilai pada kelas eksperimen sebesar 30,21 sedangkan kenaikan nilai rata-rata pada kelas kontrol sebesar 24,04. Kenaikan nilai pada kelas eksperimen lebih besar dari pada kelas kontrol terbukti perbedaan kenaikan anatara kelas eksperimen dan kelas kontrol yaitu sebesar 6,19. Setelah dilakukan posttest selanjutnya dilakukan uji hipotesis, data hasil hipotesis antara kelas eksperimen dan kelas kontrol menunjukkan $t_{\text {hitung }}$ lebih besar dari $t_{\text {tabel }}$ yaitu dengan $t_{\text {hitung }}=4,09$ dan $\mathrm{t}_{\text {tabel }}=2,07$. artinya terdapat perbedaan yang signifikan hasil posttest antara kelas eksperimen dan kelas kontrol maka Ha diterima.

Berdasarkan hasil rata-rata indikator nilai pretest dan posttest menunjukan peningkatan rata-rata pada kelas eksperimen lebih tinggi daripada kelas kontrol. Artinya kemampuan literasi matematika komponen konteks pada kelas eksperimen lebih baik baik daripada kelas kontrol. Kelas eksperimen menggunakan model Realistic Mathematics Education memiliki berpengaruh terhadap kemampuan literasi matematika daripada menggunakan model Ekplorasi, Elaborasi, Konfirmasi (EEK)

\section{SIMPULAN}

Berdasarkan hasil penelitian dan pembahasan yang diuraikan dapat disimpulkan bahwa terdapat pengaruh yang signifikan model Realistic Mathematics Education terhadap kemampuan literasi matematika komponen konteks siswa kelas V sekolah dasar gugus XIV Kota Bengkulu

\section{REFERENSI}

Abidin, Y, dkk. 2018. Pembelajaran Literasi: $\quad$ Strategi Meningkatkan Kemampuan Literasi Matematika, Sains, Membaca, dan Menulis. Jakarta: Bumi Aksara
Ajun, dkk. 2013. Development Of Long And Square Learning Devices With A Realistic Mathematical Approach Based On Bruner Theory. Jurnal Daya Matematis, Volume 1

Astuti, P. (2018). Kemampuan Literasi Matematika dan Kemampuan Berpikir Tingkat Tinggi. PRISMA 1 (Prisma Prosiding Seminar Nasional Matematika)

Diyarko., \& Waluya, B. (2016), Analisis Kemampuan Literasi Matematika Ditinjau Dari Metakognisi Dalam Pembelajaran Inkuiri Berbantu Lembar Kerja Mandiri Mailing Marge, Unnes Journal of Mathematics Education Research 5 (1) - 2016 Hal: 70-80.

Fathurrohman, M. (2015). Model-Model Pembelajaran Inovatif. Yogyakarta:ARRUZZ MEDIA

Fathani, A.H. Pengembangan Literasi Matematika Sekolah dalam Perspektif Multiple Intelligences. EduSains 2016 ISSN 2338-4387. Vol 4 No 2. 2016

Hadi, S. 2017. Pendidikan Realistik Matematik. Jakarta: Rajawali Pers.

Han, W. Dkk., (2017) Materi Pendukung Literasi Numerasi, Jakarta: Kementerian Pendidikan Dan Kebudayaan.

Karjiyati, V. Dkk. (2014) Model Pembelajaran Quantum Teaching \& Realistic Mathematics Education Dalam Pembelajaran Matematika di SD. (Jurnal Ilmiah Pendidikan Guru Sekolah Dasar, 7 (2) - 2014. Hal. 228-234

OECD, (2019), "PISA 2018 Assessment and Analiytical Framework: Mathematiics, Reading, Science, Problem Solving and Financial Literacy", Paris: Journal of $\mathrm{OECH}$ Publishing, hal 73-95.

Shoimin, A. 2014. 68 Model Pembelajaran Inovatif dalam Kurikulum 2013. Yogyakarta: AR-RUZZ Media 
Sholahudin, U. (2018). Penerapan Pendidikan Matematika Realistik (Pmr) Untuk Meningkatkan Kemampuan Literasi Matematika Siswa Kelas Iv Sdn 03 Cimaung Serang. GAUSS: Jurnal Pendidikan Matematika Vol. 01 No. 01

Sudaryono. (2016). MetodePenelitian Pendidikan. Jakarta: Prenadamedia Group

Suwarman, F.R., Wahyuni, D.S. (2018). Penerapan Model Pembelajaran Realistic Mathematics Education (RME) Untuk Meningkatan KemampuanLiterasi Matematis Siswa. Seminar Nasional Pendidikan Matematika Universitas Suryakancana (MINATKU) 2018
Tampubolon, PT. (2016). Penerapan Model Pembelajaran Matematika Realisti Indonesia Untuk Meningkatkan Aktivitas Dan Hasil Belajar Siswa Kelas Iv Sd. Jurnal Pendidikan Guru Sekolah Dasar, Vol. 1 No. 1, hlm. 190-198

Wahyuni, N.D., Jailani, J. (2017). Pengaruh Pendekatan Matematika Realistik terhadap Motivasi dan Prestasi Belajar Siswa SD. Jurnal Prima Edukasia, 5 (2), hal. 151-159

Winarni, E.W. 2018. Teori dan Praktik Penelitian Kuantitatif, Kualitatif PTK $R \& D$. Jakarta: BumiAksara

Wijaya, A. (2012). Pendidikan Matematika Realistik Suatu Alternatif Pendekatan Pembelajaran Matematika. Yogyakarta: Graha Ilmu. 